\title{
A Short Verification of the Quality of Irrigation Water in the Tea-growing Districts of South India
}

\author{
Palanivel Murugesan ${ }^{1}$, Jaganathan Anitha ${ }^{2}$, Rajendran Selvakumar ${ }^{1}$ \\ UPASI Tea Research Foundation, Regional Centre, \\ Coonoor-643 101, The Nilgiris, Tamil Nadu, India.
}

Received: July 2021

Accepted: August 2021

\begin{abstract}
Background: Variations in climatic conditions, irrigation facility and insect/pest management have brought about a massive impact on tea production. Among these the quality of the irrigation water and atmosphere related uncertainties were minimizing the tea production in right quantity and quality. The water utilized for irrigation systems can vary in quality depending on the nature and amount of dissolved salts. Minerals get dissolved into the irrigation water from various sources. They start from the disintegration of the stones and soil, including the decay of lime, gypsum and others broken up soil minerals. Salts go along with the water to the place wherever it is to being utilized. On account of the evaporation and filtration by sand particles, the salts present in the irrigation water get concentrated when the crop consumes water. Methods: Quality of the irrigation water was checked by assessing the $\mathrm{pH}$, electrical conductivity, cations $\left(\mathrm{Na}^{+}, \mathrm{K}^{+}, \mathrm{Mg}^{2+}\right.$, $\left.\mathrm{Ca}^{2+}\right)$ and anions $\left(\mathrm{Cl}^{-}, \mathrm{HCO}_{3}{ }^{-}, \mathrm{CO}_{3}{ }^{2-}\right)$. For evaluating the irrigation water quality and there are seven irrigation water samples collected from seven tea planting districts (Valparai- Tamil Nadu, Coonoor - Tamil Nadu, Gudalur - Tamil Nadu, Wayanad - Kerala, Munnar - Kerala, Vandiperiyar - Kerala, Koppa - Karnataka) in the southern states of India.

Result: After evaluations of water quality from various techniques indicated that the water in tea growing locations of the southern states of India is chemically sufficient for agricultural applications.
\end{abstract}

Key words: Irrigation, Minerals, Salts, Water.

\section{INTRODUCTION}

Tea as a plantation crop has been considered as a strong nutraceutical, non-alcoholic and widely consumed beverage after water. It is a leading cash crop in world agriculture and the major tea producing countries are China, India and to a lesser degree Sri Lanka, Kenya and Indonesia (Tea Board of India, 2009). Tea is the main crop grown all over hill stations in India states like Assam, Terai, Dooars and Darjeeling. With an annual tea production of 480 million $\mathrm{kg}$ in 2007, Assam covers approximately $17 \%$ of the world's tea production (Tea Board of India, 2007). Tea has a productive lifespan of over 100 years, but its peak production period is between the $30^{\text {th }}$ and $50^{\text {th }}$ year. Tea bushes can be raised from seed, cuttings or tissue culture (TRFK, 2012). Environmental and climatic conditions determine the rate of shoot expansion and tea yield. Various components of the environment influence the growth and productivity of tea to a different extent. Light, $\mathrm{CO}_{2}$, temperature and water availability are the most important factors determining tea productivity (De Costa et al., 2007). Decline in these factors were found to be the major cause for the reduction in tea quality and productivity among Indian tea industries.

Irrigation has the potential role to increase tea crop in the farms located in the drought prone areas or those with low moisture holding capacity (Hazarika and Muraleedharan, 2011). Improper irrigation is responsible for a $14-20 \%$ reduction in yield and 6-19\% mortality of tea plants (Bhuyan et al., 2009). In addition, under poor irrigation or drought conditions, photoinhibition could reduce source capacity and thereby impose a source limitation on tea yield (Mohotti and Lawlor 2002). A long term study had revealed the details of water requirement, frequency of irrigation and the resultant crop increase in the Nilgiris (Venkateswaran and Radhakrishnan, 2006). In this condition the quality of water supplied for irrigation is to be key noted. This situation is presently changing in numerous regions. Escalated utilization of almost all good quality of water supplies implies that new irrigation system activities and old tasks looking for new or supplemental supplies must depend on lower quality and fewer agreeable sources (Poorter et al., 2012). Maintaining a strategic distance from problems when using low-quality water supplies should be sound strategies to ensure that available water quality brings the best use (Srinivasa Gowd, 2005 and Kumaraswamy et al., 2014).

In general, groundwater contains more salt than surface water (Rawat et al., 2018). Furthermore, the amount of salt found in the irrigation system is more significant in dry and semi-arid areas than in wet and the sub-wet regions

*Corresponding author's E-mail: mpm_sun@yahoo.co.in

1UPASI Tea Research Foundation, Regional Centre, Coonoor-643 101, The Nilgiris, Tamil Nadu, India.

2Department of Biochemistry, Kongunadu Arts and Science College (Autonomous), Coimbatore-641 029, Tamil Nadu, India. 
(Robinson, 1994). Salt is classified as a water-soluble compound and comes from a mixture of an acid Baruah and a metal. The salinity of the water system is, for the most part, a combination of different salts. The most abundant cations and anions in irrigation water were sodium $\left(\mathrm{Na}^{+}\right)$, calcium $\left(\mathrm{Ca}^{2+}\right)$, magnesium $\left(\mathrm{Mg}^{2+}\right)$, chloride $(\mathrm{Cl})$ and bicarbonate $\left(\mathrm{HCO}^{3-}\right)$. Understanding the relationship between water components helps to estimate the degree of compatibility of tea crops (Piper, 1994). Specific elements formed as indicators of value-related problems. The quality of the irrigation water affects the tea shoot expansion and reduces the overall yield (Hajipoland, 2017). Therefore, achieving a satisfactory crop harvest without learning soil, water salinity and appropriate water management techniques will be challenging task (Walter et al., 2018). Hence based on the facts, the present study was intended to study the water quality parameters to make appropriate decisions for fixing potential irrigation problems tea crop management.

\section{MATERIALS AND METHODS Collection of water samples}

The irrigation water samples were collected form seven different tea planting districts from Southern Indian states including Tamil Nadu (Valparai, Coonoor, Gudalur), Kerala (Wayanad and Munnar) and Karnataka (Vandiperiyar and Koppa). During drought season, $1000 \mathrm{ml}$ of water samples were collected in air tight HDPE bottles priorily rinsed with acid. The collected water samples were stored below $40^{\circ} \mathrm{C}$ for further analysis.

\section{Physico-chemical analysis of water}

All the Physico-chemical parameters were analysed at Research Laboratory, UPASI Tea Research Foundation, Regional Station, Coonoor, Tamil Nadu, India. The physical parameters like $\mathrm{pH}$, electrical conductivity $(\mathrm{EC})$ and total hardness (TH) were analysed. The hydrochemical parameters like calcium $\left(\mathrm{Ca}^{2+}\right)$, magnesium $\left(\mathrm{Mg}^{2+}\right)$, sodium $\left(\mathrm{Na}^{+}\right)$, potassium $\left(\mathrm{K}^{+}\right)$was analysed by EDTA titrimetric and flame photometric methods given by Chris Smith et al., (2014) and Sawyer and McCarthy (1967). Volumetric methods were utilized to estimate the anions like bicarbonate
$\left(\mathrm{HCO}^{3-}\right)$, carbonate $\left(\mathrm{CO}^{3-}\right)$ and $\mathrm{Chloride}(\mathrm{Cl})$ respectively. All quantified ions in milligrams per liter ( $\mathrm{mg} / \mathrm{L}$ ) and compared with the recommended value of Food and Agricultural Organization (FAO).

\section{Calculation of sodium absorption ratio (SAR)}

Sodium absorption ratio (SAR) is an essential parameter for deciding the suitability of water for agricultural purposes (Raju and Gowd., 2006) and determined by the following calculation:

$$
\mathrm{SAR}=\sqrt{\left[\left(\mathrm{Ca}^{2+}+\mathrm{Mg}^{2+}\right) / 2\right]} \text { (Concentrations are in meq/l) }
$$

\section{RESULTS AND DISCUSSION}

Salinity is causing decline in soil productivity and crop yield which results in severe degradation. Salinity is causing decline in soil productivity and crop yield which results in severe degradation. Salinity is a major abiotic stress limiting growth and productivity of plants in many areas of the world due to increasing use of poor quality of water for irrigation and soil salinization. Salinity is a major abiotic stress limiting growth and productivity of plants in many areas of the world due to increasing use of poor quality of water for irrigation and soil salinization.

Salinity is the major abiotic stress limiting the crop growth and productivity of plants in any of the climatic condition. This happens because of increasing use of poor quality of water for irrigation. Hence it is in trendy need to analyse the quality of water used for irrigation purpose. In the present investigation the water samples was collected from seven South Indian districts Valparai, Coonoor, Gudalur, Wayanad, Munnar, Vandiperiyar and Koppa was subjected for the quantification of physico-chemical parameters and the results were tabulated in Table 1 and Fig (1-6) respectively.

\section{Physical parameters}

$\mathrm{pH}$ and $\mathrm{EC}$ were found to be the physical and basic profile of any kind of water. $\mathrm{pH}$ is one of the essential parameters of water which decides the acidic and alkaline nature of water. The $\mathrm{pH}$ of irrigation water usually is in the range

Table 1: Irrigation water quality in tea growing areas of Southern India.

\begin{tabular}{|c|c|c|c|c|c|c|c|c|c|c|}
\hline \multirow{2}{*}{$\begin{array}{l}\text { Water } \\
\text { source }\end{array}$} & \multirow{2}{*}{$\mathrm{pH}$} & \multirow{2}{*}{$\begin{array}{c}\mathrm{EC} \\
\mathrm{dSm}{ }^{-1}\end{array}$} & \multicolumn{3}{|c|}{ Hardness as $\mathrm{CaCO}_{3} \mathrm{mg} / \mathrm{L}$} & \multirow{2}{*}{$\begin{array}{l}\text { Alkalinity as } \\
\mathrm{HCO}_{3}^{-} \mathrm{mg} / \mathrm{L}\end{array}$} & \multirow{2}{*}{$\begin{array}{c}\mathrm{K}^{+} \\
\mathrm{mg} / \mathrm{L}\end{array}$} & \multirow{2}{*}{$\begin{array}{l}\mathrm{Na}^{+} \\
\mathrm{mg} / \mathrm{L}\end{array}$} & \multirow{2}{*}{$\begin{array}{c}\mathrm{Cl}^{-} \\
\mathrm{mg} / \mathrm{L}\end{array}$} & \multirow{2}{*}{ SAR } \\
\hline & & & Total & $\mathrm{Ca}^{2+}$ & $\mathrm{Mg}^{2+}$ & & & & & \\
\hline Valparai & 6.10 & 0.06 & 20 & 10 & 10 & 12 & 0.94 & 2.62 & 57 & 0.3 \\
\hline Coonoor & 6.00 & 0.05 & 18 & 8 & 10 & 12 & 1.34 & 3.73 & 57 & 0.4 \\
\hline Gudalur & 7.37 & 0.25 & 106 & 94 & 12 & 96 & 1.78 & 12.35 & 80 & 0.5 \\
\hline Wayanad & 7.20 & 0.06 & 11 & 4 & 7 & 40 & 0.46 & 1.81 & 40 & 0.2 \\
\hline Munnar & 6.20 & 0.02 & 9 & 5 & 4 & 18 & 0.90 & 1.55 & 50 & 0.2 \\
\hline Vandiperiyar & 7.65 & 0.28 & 144 & 78 & 66 & 176 & 1.78 & 19.85 & 110 & 0.7 \\
\hline Koppa & 6.80 & 0.17 & 46 & 29 & 17 & 46 & 2.22 & 19.47 & 100 & 0.9 \\
\hline SE & 0.01 & 0.01 & 3.09 & 1.89 & 0.59 & 1.41 & 0.01 & 0.02 & 1.32 & 0.04 \\
\hline CD @5\% & 0.01 & 0.01 & 6.73 & 4.11 & 1.28 & 3.08 & 0.02 & 0.04 & 2.88 & 0.09 \\
\hline CD@1\% & 0.01 & 0.02 & 9.44 & 5.76 & 1.79 & 4.31 & 0.03 & 0.06 & 4.04 & 0.13 \\
\hline
\end{tabular}


between at least 6.50 and a limit of 8.40 , while deviating this range creates a nutritional imbalance to crops (FAO, 2017). The experimental data (Table 1) showed that the water sample collected from the various irrigation sites has $\mathrm{pH}$ range from acidic to neutral. From the seven water samples analysed, the significant part of the zone having a $\mathrm{pH}$ lower than 7.00 was noted as Valparai, Coonoor, Munnar and Koppa (Fig 1). The $\mathrm{pH}$ of the tea crop soils should range

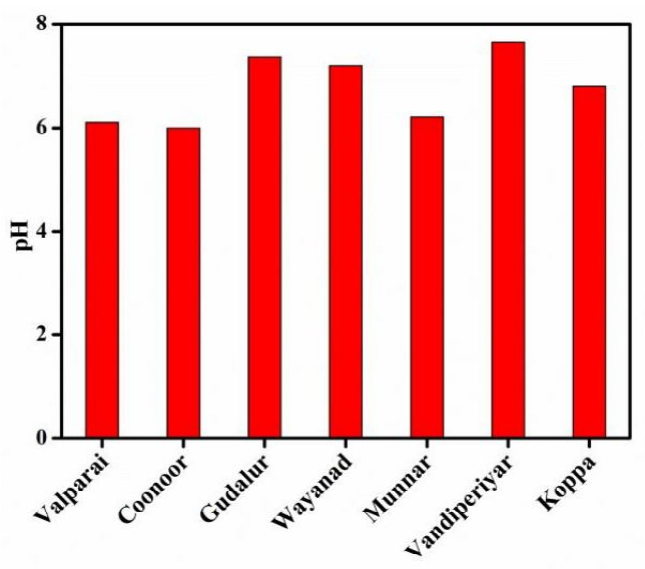

Fig 1: $\mathrm{pH}$ range of irrigation water.

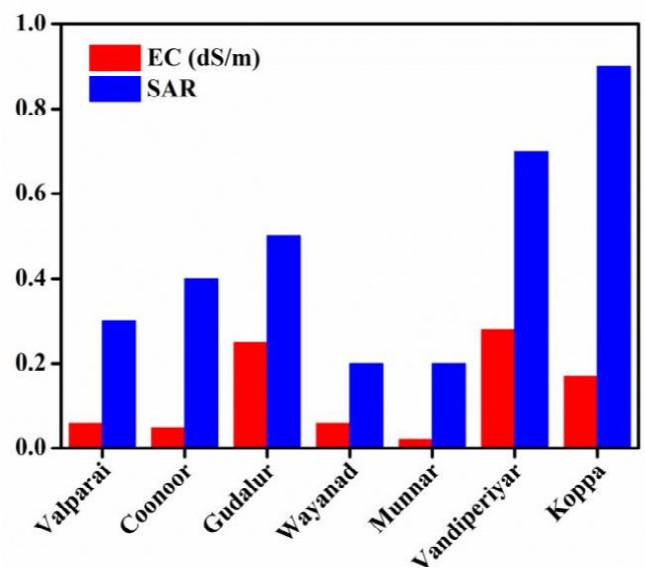

Fig 2: EC and SAR of irrigation water.

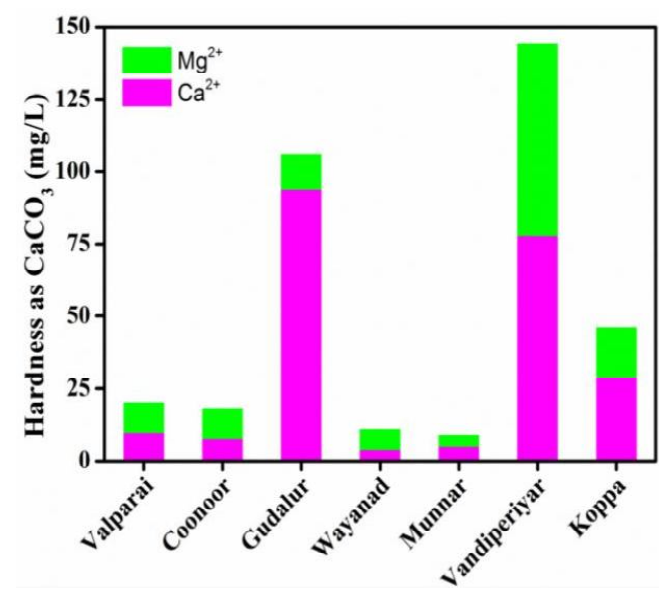

Fig 3: Hardness of irrigation water. between 4.80 and 5.00 (Bhupen et al., 2013). In contrast, $\mathrm{pH}$ values obtained in our current findings postulates that the irrigation zones of our interest acquired acidic nature of water.

The saltiness of the irrigation water gives an high impact on crop harvest and it is estimated by electrical conductivity (EC). Water with EC under $0.30 \mathrm{dS} / \mathrm{m}$ viewed as better for both surfaces and sprinkler irrigation systems and that exceeds $3.00 \mathrm{dS} / \mathrm{m}$ is unacceptable for cultivation purposes as per FAO standards (Table 2). In this experiment, the electrical conductivity (EC) of water is being between 0.02 and $0.28 \mathrm{dS} / \mathrm{m}$. A high salt substance in the irrigation water indicates to the saline soil. EC of water samples from different locations' most extreme value is $0.28 \mathrm{dS} / \mathrm{m}$ and the least amount is $0.10 \mathrm{dS} / \mathrm{m}$ and which alludes to that the water is below to water system according to FAO specification (Ayers and Westcot., 1994). All water tests aside from Vandiperiyar, Gudalur and Koppa areas are beneath $0.10 \mathrm{dS} / \mathrm{m}$, which is indicating good sign for irrigation water (Fig 2). The water utilized for irrigation can vary incredibly in the quality, depending on the nature and the number of dissolved salts (Ayers and Westcot, 1994). The crop utilizes irrigation water containing the average dissolved salts whose excess of saltiness stored in the root zone is harming to yield (Zhang et al., 2007).

The classification of water depends on the total hardness $(\mathrm{TH})$. Most of the water test of the experiment locations fall in the soft to the hard range. The cations $\mathrm{Mg}^{2+}$

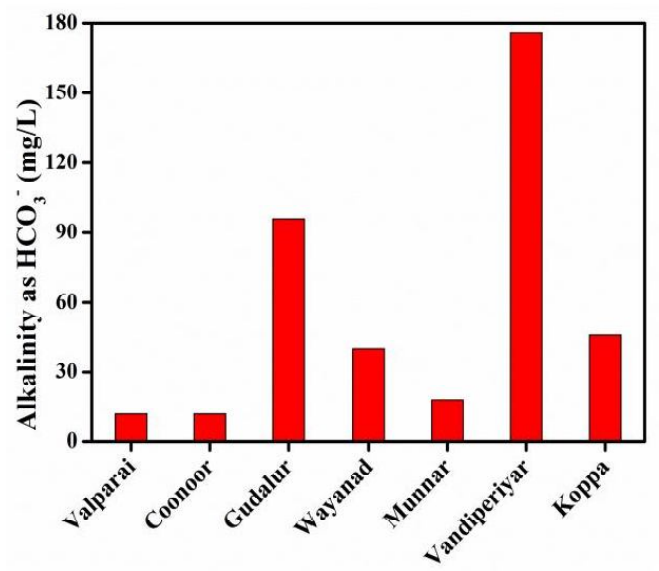

Fig 4: Alkalinity of irrigation water.

Table 2: Profile of surface and sprinkler water FAO Specification.

\begin{tabular}{lcc}
\hline \multirow{2}{*}{ Parameters } & \multicolumn{2}{c}{ Specification } \\
\cline { 2 - 3 } & Surface irrigation & Sprinkler irrigation \\
\hline $\mathrm{pH}$ & 6.5 to 8.4 & 6.5 to 8.4 \\
$\mathrm{dS} / \mathrm{m}$ & $<3.0$ & $<0.7$ \\
$\mathrm{HCO}_{3}-\mathrm{mg} / \mathrm{L}$ & - & 518 \\
Sodium $\mathrm{mg} / \mathrm{L}$ & 69 & 69 \\
$\mathrm{SAR}$ & $<9$ & $<9$ \\
(Sodium adsorption ratio) & & \\
Chlorides mg/L & $<350$ & $<106$ \\
\hline
\end{tabular}




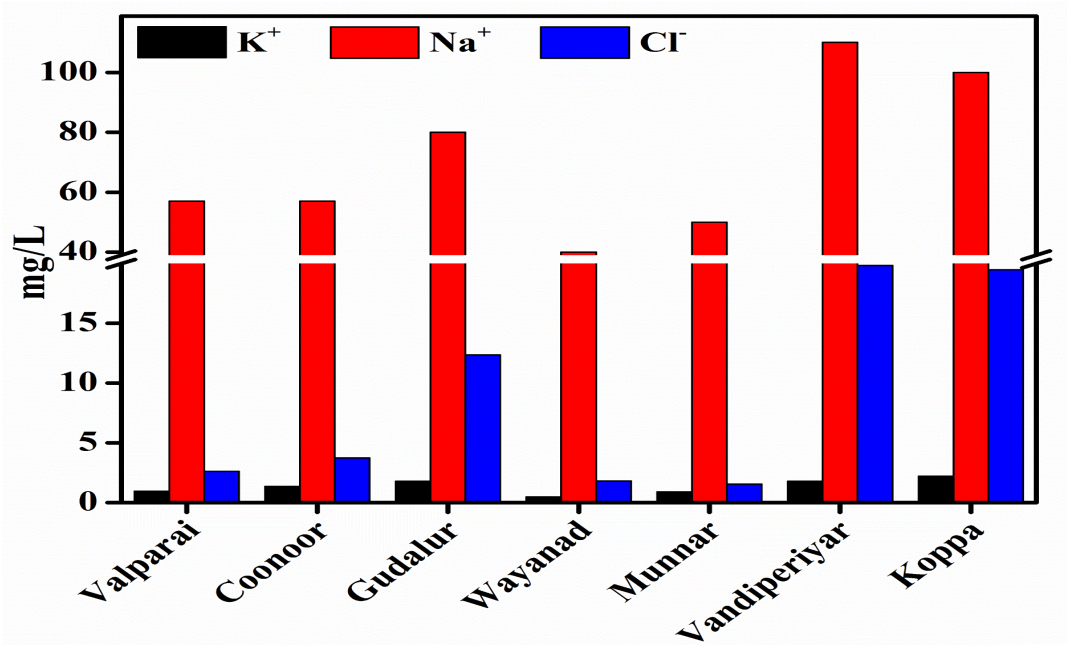

Fig 5: Potassium, sodium and chlorides of irrigation water.

and $\mathrm{Ca}^{2+}$ contribute to the hardness of the water. $\mathrm{Mg}^{2+}$ ranges from $4 \mathrm{mg} / \mathrm{L}$ and the most extreme was $66 \mathrm{mg} / \mathrm{L}$. Ca ${ }^{2+}$ is between 4 and $94 \mathrm{mg} / \mathrm{L}$ (Fig 3). Table 1 demonstrates that the total hardness (Sawyer and McCarth, 1967), which is related to calcium and magnesium. When the sum of $\mathrm{Mg}^{2+}$ and $\mathrm{Ca}^{2+}$ is under $75 \mathrm{mg} / \mathrm{L}$, then the water was classified as soft water.

Most of the water samples except for Vandiperiyar and Gudalur areas are soft in nature. However, for a good water system TH $94 \mathrm{mg} / \mathrm{l}$ is not very high and is acceptable for irrigation. The level of Sodium (1.81-19.85 mg/L) and potassium $(0.46-2.20 \mathrm{mg} / \mathrm{L})$ suggested the salinity nature of the water (Fig 5).

The significant anions present in the samples are $\mathrm{Cl}-$ and $\mathrm{HCO}^{3-}$. They were present in the range of $42-110 \mathrm{mg} / \mathrm{L}$ and $12-175 \mathrm{mg} / \mathrm{L}$, respectively (Fig 4). Cl- comes from the anion of salt in the water (Mondal et al., 2010). High pH's above 8.50 is frequently brought about by high bicarbonate $\left(\mathrm{HCO}_{3}{ }^{-}\right)$and carbonate $\left(\mathrm{CO}_{3}{ }^{2-}\right)$ known as alkalinity. High carbonates cause calcium and magnesium particles to form insoluble minerals leaving sodium as the prevailing particle in solution. As portrayed in the sodium risk segment, this soluble water could strengthen the effect of high SAR water on acidic soil conditions (Rawat et al., 2018). Moreover, bicarbonate concentrates can be dangerous for drip or sprinkler irrigation system frameworks when calcite or scale development causes decreased stream rates through holes or emitters (Adamu, 2013). Table 1 exhibits the alkalinity was very much below the acceptable max limit of $518 \mathrm{mg} / \mathrm{L}$ (Table 2). These results are indicating water quality is good for cultivation.

At the point when the amount of the $\mathrm{Na}^{+}$is high in the irrigation water, it keeps an eye on that $\mathrm{Na}^{+}$consumed by the more significant part of the earth particles, uprooting $\mathrm{Mg}^{2+}$ and $\mathrm{Ca}^{2+}$ (Allende and Monaghan, 2015). These procedures lessen the porosity and the outcomes in soil with poor interior seepage. The flow of air and water is confining amid wet conditions. Sodium begins to alleviate the development of most yield and field plants when its focus in water surpasses $69 \mathrm{mg} / \mathrm{L}$ or SAR 9 . Table 1 demonstrates the sodium levels are under $20 \mathrm{mg} / \mathrm{L}$ and that water is viewing as a good. Most of the samples are falling into this category, and it is proving as good quality water (Fig 5).

Overabundance of sodium in the water produces unwanted impacts of changing the soil properties and lessening the penetration limit (Kelley, 1957). It is necessary to evaluate convergence of $\mathrm{Na}+$ is fundamental in order to reasonable the nature of water system. How much the water goes into the cation trade responses in the soil was demonstrated by SAR (Todd, 1959; Richards, 1954). Table 1 demonstrates the characterization of water quality dependent on SAR. All samples are low in saltiness. As indicated by FAO specification, when the SAR esteems less than $9 \mathrm{meq} / \mathrm{L}$ (Table 2), they considered superior quality to the irrigation water. The majority of samples collected from southern regions were below $1 \mathrm{meq} / \mathrm{L}$ (Fig 6).

The most widely recognized harmfulness is from chloride in the water system water. Chloride isn't adsorbed or kept down by soils, hence it moves promptly with the soil water, is taken up by the crop, moves in the happening stream and stored in the leaves. On the off chance that the chloride fixation in the leaves surpasses the resistance of the harvest, injury side effects grow, for example, leaf consumption or drying of leaf tissue. Typically, plant injury happens first at the leaf tips (which is regular for chloride harmfulness) and advances from the tip back along the edges as seriousness increments. Exorbitant putrefaction (dead tissue) is often accompanied by early leaf drop or defoliation (FAO, 2017). FAO specifies the chlorides tolerance limits of irrigation water and all the region chloride contents is within the specified limits except vandiperiyar region but outlier for sprinkler is very narrow (Fig 5).

Issues experienced where the irrigation system action is weak in the agricultural waste soils and where the water logging enables the water system to rise near the root zone of plants causing aggregation of sodium salts in soils 
specification through slim ascent following surface dissipation. The sodium or antacid peril in the utilization of water for the irrigation system is controlling by the total and relative concentration of cations (Rawat et al., 2018). General movement of sodium particle in the trade response with soil is communicating regards SAR.

\section{CONCLUSION}

Results of the present investigation specifies that the water taken from the experimental regions is very soft to moderately hard and acidic to neutral. Most of the areas in southern India are having the quality of the water to meet the FAO standards was in accordance with the current findings. The $\mathrm{pH}$ and $\mathrm{EC}$ values show that irrigation water quality is not affected by external factors. At last, it is confirming that water within the experimental limits is suitable for irrigation purposes without any water treatment process.

\section{ACKNOWLEDGEMENT}

The authors are thankful to K.G. Udayabhanu, Deputy Director UPASI Tea Research Foundation, Regional Centre, Coonoor, The Nilgiris, Tamil Nadu, India, for enduring bearing, reliable help, and backing. The authors are thankful to all the HODs of regional centers for collecting the water samples.

\section{REFERENCES}

Adamu, G.K. (2013). Quality of irrigation water and soil characteristics of watari irrigation project. American Journal of Engineering Research. 2(3): 59-68.

Allende, A. and Monaghan, J. (2015). Irrigation water quality for leafy crops: A perspective of risks and potential solutions. International Journal of Environmental Research and Public Health. 12: 7457-7477.

Ayers, R.S. and Westcot, D.W. (1994). Water quality for agriculture. FAO Irrigation and Drainage Paper. 29 Rev. 1.

Bhupen, K. Baruah, Bhanita Das, Chitrani Medhi and Abani K. Misra. (2013). Fertility Status of Soil in the Tea Garden Belts of Golaghat District, Assam, India. Journal of Chemistry. 6 pages.

Chris Smith, J.D., Oster and Sposito, G. (2014). Potassium and magnesium in irrigation water quality assessment. Agricultural Water Management. 157.

De Costa, W.J.A.M., Mohotti, A.J., Wijeratne, M.A. (2007). Ecophysiology of Tea, Braz. J. Plant Physiol. Oct./Dec. vol.19 no.4 Londrina.

Food and Agriculture Organization of the United Nations (FAO). (2017). Does improved irrigation technology save water? A review of the evidence. Cairo.

Hajiboland, R. (2017). Environmental and nutritional requirements for tea cultivation. Folia Hort. 29(2): 199-220.

Hazarika, M. and Muraleedharan, N. (2011). Tea in India: An overview, Country profile Two and a Bud. 58: 3-9.
Kelley, W.P. (1957). Alkali Soils-Their Formation, Properties and Reclamation. Reinhold, New York.

Kumarasamy, P., Hans-Uwe Dahms, Hyoung-Joo Jeon, A. Rajendran and R. Arthur James. (2014). Irrigation water quality assessment-an example from the Tamiraparani river, Southern India. Arab J. Geosci. 7: 5209-5220.

Mondal, N.C., Singh, V.P., Singh, V.S. and Saxena, V.K. (2010). Determining the interaction between groundwater and saline water through groundwater major ions chemistry, Journal of Hydrology. 388: 1-2, 100-111.

Piper, A.M., (1994). A graphical procedure in the geochemical interpretation of water analysis. Transactions, American Geophysical Union. 25: 914-923.

Poorter, H., Niklas, K.J., Reich, P.B., Oleksyn, J., Poot, P. and Mommer, L. (2012). Biomass allocation to leaves, stems and roots: Meta-analyses of interspecific variation and environmental control. New Phytol. 193: 30-50.

Raju, N.J. (2006). Hydrogeochemical parameters for assessment of groundwater quality in the upper Gunjanaeru River basin, Cuddapah District, Andhara Pradesh, South India, Environmental Geology. 8: 156-178.

Rawat, K.S., Singh, S.K. and Gautam, S.K. (2018). Assessment of groundwater quality for irrigation use: A peninsular case study. Applied Water Science. volume 8.

Richards L.A. (1954). Diagnosis and Improvement of Saline and Alkaline Soils, US Department of Agriculture Hand Book, Washington, 60.

Robinson, D. (1994). The responses of plants to nonuniform supplies of nutrients. New Phytol. 127: 635-674.

Sawyer, C. and McCarthy, P. (1967). Chemical and Sanitary Engineering, $2^{\text {nd }}$ edn. McGraw-Hill, New York.

Srinivasa Gowd, S. (2005). Assessment of groundwater quality for drinking and irrigation purpose: A case study of Peddavanka watershed, Anantapur District, Andhra Pradesh, India, Environmental Geology. 48: 702-712.

Tea Board of India (2007). Production of Tea in India. Tea Statistics Annual Report. Kolkata, India: Tea Board of India.

Tea Board of India (2009). Growers and Areas under Tea. Tea Statistics Annual Report. Kolkata, India: Tea Board of India.

Todd, D.K. (1959). 'Groundwater Hydrology', Wiley, New York, pp. 336. TRFK (Tea Research Foundation of Kenya), (2012). Tea Cultivation Manual for Good Agricultural Practices. $1^{\text {st }}$ ed. Nairobi, Kenya.

Venkateswaran, G. and Radhakrishnan, B. (2011). Studies on the Effect of Drip Irrigation in Mature Clonal Tea. In: Abstracts: World Tea Science Congress, Tocklai Experimental Station, Jorhat, Assam. pp.7.

Walter, A., Silk, W.K. and Schurr, U. (2000). Effect of soil pH on growth and cation deposition in the root tip of Zea mays L. J. Plant Growth Regul. 19: 65-76.

Zhang, H., Rong, H. and Pilbeam, D. (2007). Signalling mechanisms underlying the morphological responses of the root system to nitrogen in Arabidopsis thaliana. J. Exp. Bot. 58: 23292338. 